\title{
Adoption of improved wheat production technology in Gorche district, Ethiopia
}

\author{
Aklilu Atinafu ${ }^{1}$, Messeret Lejebo $^{2}$ and Abera Alemu² ${ }^{*}$ (i)
}

\begin{abstract}
Background: Ethiopia is a major producer of cereals and the largest wheat producer in sub-Saharan Africa. The wheat sub-sector is strategic for the Government of Ethiopia, where wheat has several food uses which can be prepared in modern or culturally processed techniques. Crop production and productivity including wheat is a function of all the recommended technology packages not only variety. Adoption of all recommended production technologies play a significant role in improving wheat production and productivity which in turn has clear implication on food security of Ethiopia and welfare of the farmers. Recent studies conducted focused on adoption of only single technology, primarily variety adoption, without considering its associated production technologies. Therefore, this study attempts to identify the major factors determining adoption of improved wheat (Shorma, Degelu, Danda and Kakawa) production technologies in Gorche district, Ethiopia.
\end{abstract}

Methodology: The finding of this study is based on primary data collected from 150 randomly selected households and secondary data collected from literature review. Primary data were collected from these respondents using structured and semi-structured interviews. Tobit model was applied to identify factors affecting the adoption and intensity of adoption of improved wheat production technology in the study area.

Result: The results of tobit model showed that land holding, annual income, level of education, membership in social organizations, access to credit, and positive attitude toward improved wheat production technology positively and significantly influence the adoption and intensity of adoption of the improved wheat production technology. On the other hand, age and market distance significantly and negatively impact adoption and intensity of adoption of the improved wheat production technology.

Conclusion: Adoption and intensity of adoption of improved wheat production technology is a function of socioeconomic, demographic, farmer's attitude and institutional factors. The policy relevance of our findings is that investment in education, strengthening social capital through available local social networks, provision of attitude-focused training and continuous technical support on improved wheat production technologies, improving income, expanding access to credit and market are important to facilitate adoption of improved wheat production technologies. Hence, addressing constraints associated with credit and market access, improvement in income, attitudes of farmers towards improved technology would improve the adoption and intensity of adoption of improved wheat production technologies.

Keywords: Adoption, Technology, Tobit model, Wheat

*Correspondence: abrish8353@gmail.com

2 Department of Rural Development and Agricultural Extension, College of Agriculture, Hawassa University, Hawassa, Ethiopia

Full list of author information is available at the end of the article

\section{Background}

Ethiopia is a major producer of cereals such as teff, maize, wheat, sorghum and rice and the largest wheat producer in sub-Saharan Africa. The wheat sub-sector is strategic for the Government of Ethiopia [1]. According to original author(s) and the source, provide a link to the Creative Commons licence, and indicate if changes were made. The images or other third party material in this article are included in the article's Creative Commons licence, unless indicated otherwise in a credit line to the material. If material is not included in the article's Creative Commons licence and your intended use is not permitted by statutory regulation or exceeds the permitted use, you will need to obtain permission directly from the copyright holder. To view a copy of this licence, visit http://creativecommons.org/licenses/by/4.0/. The Creative Commons Public Domain Dedication waiver (http://creativeco mmons.org/publicdomain/zero/1.0/) applies to the data made available in this article, unless otherwise stated in a credit line to the data. 
central statistics agency, the main wheat growing areas of the countries are the highlands of the central, southeast and northwest areas. Regional production shares are as follows: Oromia (57.4\%), Amhara (27\%), South Nation Nationality and People (8.7\%) and Tigray (6.2\%) [2]. In Ethiopia both production and cultivated area of wheat have increased over the past 10 years. This growth is attributed to heavy investment on extension programs and increased supply of inputs. For example, in the crop year of 2016/2017, from the total land allocated for cereal crops, wheat stands in fourth by covering $13.49 \%$ of the total areas preceded by teff, maize, and sorghum. In 2016/217, the total wheat area was 1.69 million hectares with a production of 4.52 million tonnes from 4.99 million holders [19]. In Ethiopia, approximately $32 \%$ of total farmers are engaged in grain production [1]. Along with the production increase in recent years, consumption of wheat and wheat products has also expanded significantly [1].

Despite its potential, Ethiopia remains a net importer of wheat. For instance, in 2016 the Ethiopian Grain Trade Enterprise imported 750 thousand tonnes from Russia and Argentina and 300 thousand tonnes through food aid, resulting in 1.05 million tonnes of imported wheat [1].

In Ethiopia wheat is a major staple crop and is consumed heavily in different forms [1]. In the country, wheat has several food uses which can be prepared in modern or culturally processed technique. Ingera is one of the traditional foods that can be prepared by using wheat. Besides, pasta and macaroni can also prepared in industrial processed way [3]. At the same time, wheat straw is commonly used as a roof tacking material and as a feed for animals [4].

Although wheat shows an increasing trend in production and productivity, Ethiopian wheat yield is still relatively low by global standards. The main reasons are limited storage capacity, lack of demand due to poor quality of local wheat, lack of grade and standardization, existence of crop worm and diseases, shortage and price of input, shortage of infrastructure, subsistence or traditional production system, farmer price cheating by traders and very limited irrigation access $[4,20]$.

Several studies aimed at wheat adoption focuses on studying adoption of varieties without considering its associated production technologies [9, 21-27]. Production and productivity are the function of all the recommended packages, not only variety. Adoptions of all scientifically recommended production technologies play a significant role in wheat production and productivity. Therefore, this study was conducted to identify the major factors determining adoption of improved wheat production technologies in Gorche district, Ethiopia, by focusing on different packages of the wheat production technologies.

\section{Research methodology Description of the study area}

The study was conducted in Gorche district located in the Sidama region, Ethiopia. The district capital, Gorche town, is located at the distance of $317 \mathrm{~km}$ from Addis Ababa, capital of the country, and $44 \mathrm{~km}$ from Hawassa which is the capital city of Sidama region. The district is subdivided into 21 rural and 3 urban totals of 24 Kebeles [5]. According to the 2007 census, the projected total population number of the district is 105,472; and of which 53,484 (50.7\%) males and 51,988 (49.3\%) are females with a total of 25,881 households consisting 24,802 male-headed household and 1079 female-headed household (see Fig. 1).

\section{Sampling techniques}

Multi-stage sampling technique was employed to select the representative sample for this study. In the first stage, Gorche district of the Sidama region was purposively selected due to its agroecology being suitable and its potential for wheat production. In the second stage, the district was stratified into two based on their agroecology (high land and mid-land). In the third stage, three Kebeles were selected randomly ( 2 Kebeles from highland and 1 Kebele from low land). Following this Yamane [6] sample determination formula was applied to decide the sample for this study. There are 3750 farming households in these three Kebeles. Inserting the number in the formula, the total sample selected for this study was 150 households. The minimum level of precision level is acceptable at $10 \%$ [18]. However, in this study we assumed $8 \%$ precision level considering the available resources to conduct the study:

$$
n=\frac{\mathbf{N}}{1+\mathbf{N}(\boldsymbol{e})^{2}},
$$

where $n$ is sample size to be computed, $\mathrm{N}$ is the total size of farming households in the study area, and $e$ is the level of precision. In the fourth stage, respective sample of the each Kebeles was selected randomly after deciding their respective sample size based on probability proportional to size sampling method.

\section{Methods of data collection}

Structured and semi-structured household survey questionnaires were used to collect primary data from the respondents from December 2019 to January 2020 after pretesting and making required amendments. Faceto-face interviews were made with 150 farmers after providing training for enumerators. Reviews of related 


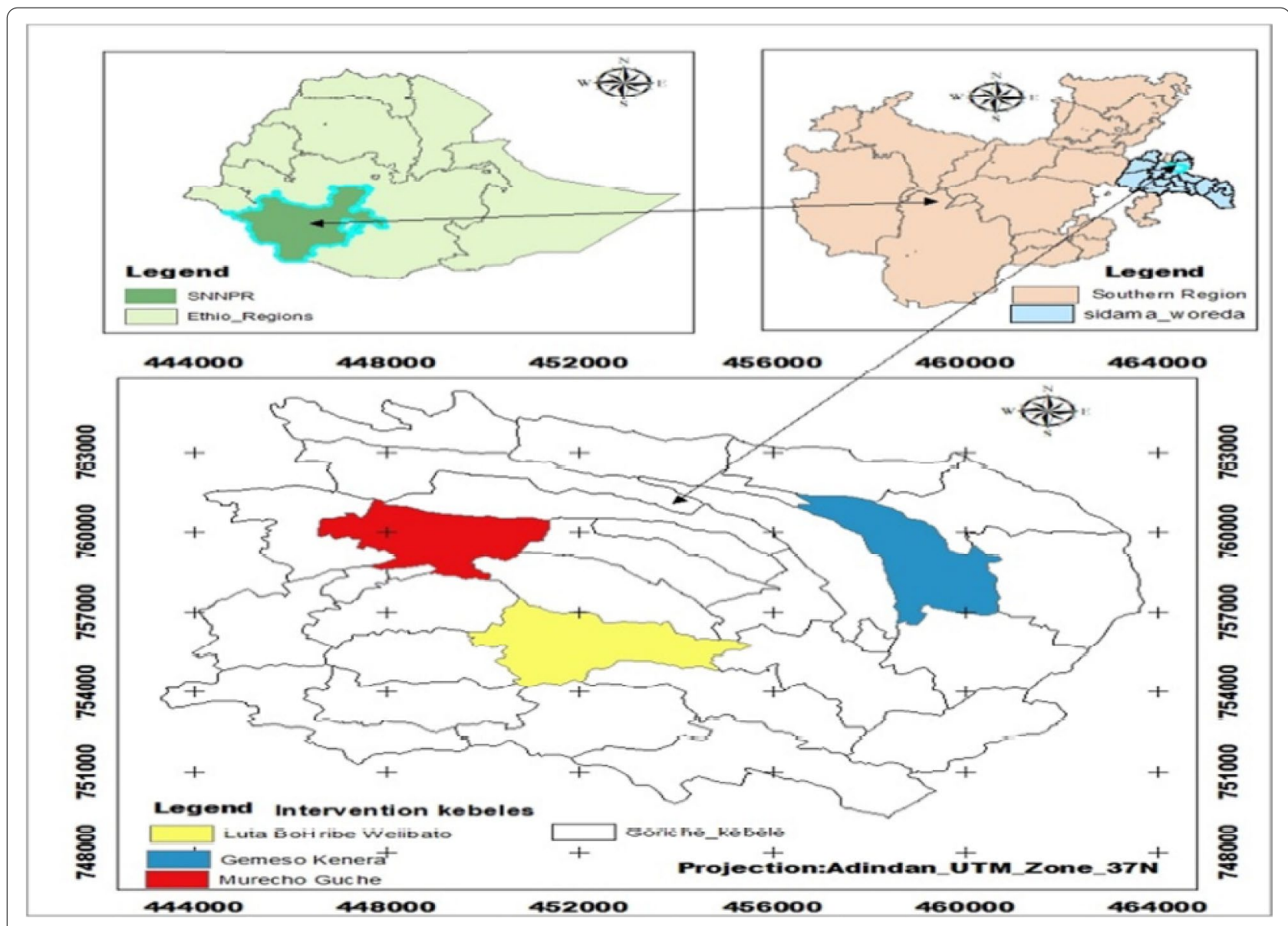

Fig. 1 Map of the study area

literatures were made to collect the required secondary data.

\section{Methods of data analysis}

Data collected from the respondents were analyzed using the Stata version 13. Following this, taking the research objectives into account, tobit model was implemented to identify factors affecting adoption and intensity of adoption of improved wheat production technology. It is necessary to determine the level of the adoption for each farm household before analyzing the determinants of adoption. Based on this, non-adopters are farmers who are not growing an improved variety of wheat whereas adopters are those farmers who are growing improved variety with some of the recommended agronomic practices of wheat production. As only five agronomic practices (improved variety, seed rate, plowing frequency, weeding frequency, and fertilizer application rate), are implemented in the study area, intensity of adoption of the wheat technology package for those of adopters can be computed using the following formula considering five package components. The adoption indexes of individual farmers following the suggestion of Maddalla [30] are:

$$
\mathrm{AL} i \sum_{i=1}^{n}\left(\frac{\mathrm{AT} i}{\mathrm{RT} i}\right) \mathrm{NP}
$$

where $\mathrm{AL} i=$ is adoption index of $i$ th farmer; $i=1,2,3 \ldots$, $n ; n$ is total number of farmers; AT $=$ is the level or quantity of input the farmer actually applied; $\mathrm{RT}=$ is the recommended level or quantity of an input he/she ought to apply, and $\mathrm{NP}=$ is the number of practice.

After summing up for all the elements of the package of recommendations, a maximum obtainable adoption score is fixed at $1 \%$ or $100 \%$. Based on Eq. (2), the following specific formula was applied for this study:

$$
\mathrm{AL} i \sum_{i=1}^{n}\left(\frac{\mathrm{SA}}{\mathrm{SR}}+\frac{\mathrm{PFA}}{\mathrm{PFR}}+\frac{\mathrm{WFA}}{\mathrm{WFR}}+\frac{\mathrm{FA}}{\mathrm{FR}}+\frac{\mathrm{LCIWS}}{\mathrm{LCTS}}\right) \mathrm{NP},
$$


where $\mathrm{SA}=$ seed applied per hectare and $\mathrm{SR}=$ seed recommended per hectare; $F A=$ fertilizer applied per hectare and $\mathrm{FR}=$ fertilizer recommended per hectare; PFA $=$ plowing frequency applied and PFR $=$ plowing frequency recommended; WFA $=$ Weeding Frequency Applied and WFR = weeding frequency recommended; LCIWS = land covered by improved wheat seed, and LCTS $=$ land covered by total wheat seed

Hence, from this, adoption index is a continuous dependent variable that takes value 1 for adoption and 0 for no adoption.

\section{Results and discussion}

After review of literature and personal observations by authors, we have hypothesized different demographic, socio-economic, psychological and institutional factors that would affect both adoption and intensity of adoption of improved wheat production technology (see Table 1).

\section{Determinants of adoption and intensity of adoption of improved wheat production technology}

In this section, discussion of the empirical findings of the econometric model is presented. Table [2] shows the results of the tobit model used to identify the major determinants of adoption and intensity of adoption of the improved wheat production technology. Columns a, b, c, respectively, show probability change of adoption of wheat production packages, adoption intensity change and adoption total change. The results of tobit model were further used to assess the effects of changes in the explanatory variables on adoption and intensity of adoption of wheat technologies. Accordingly, the effect of changes in the explanatory variables on the probability of adoption and intensity of use of wheat production package was computed as suggested by Ref. [17]. Out of 16 hypothesized independent variables, eight of them were found to be statistically significant in determining the adoption and intensity of adoption of improved wheat production technology. These include age of household head, educational level of the household head, membership in social organization, attitude towards the technology, distance to market, access to credit, annual income of the household and total landholding. Discussion of each of the significant variables is presented as follows.

\section{Age}

The analyses results demonstrate that respondent's age negatively determine the adoption and intensity of adoption of improved wheat production technology at less than 5\% significance level. Furthermore, marginal effect results computed in Table 2 indicate that a one year increase in age of the respondents decrease the probability of adoption of improved wheat production technology by $0.031 \%$ and intensity of use of wheat production technology by $0.459 \%$. This shows that in the study area, older farmers less adopt new technology because their

Table 1 Definition and measurement of variables used in the tobit model

\begin{tabular}{|c|c|c|}
\hline Variables & Type & Definition and measurement \\
\hline Adoption index(ADOPI) & 1 & $\begin{array}{l}\text { Adoption index that takes value between } 0 \text { and } 1 \text { which is calculated based on the technologies } \\
\text { adopted in relation to the recommended level }\end{array}$ \\
\hline Age $(A G E H H)$ & 1 & Age of the household in year \\
\hline Family size (FMSZ) & 1 & Family size of the household in number \\
\hline $\operatorname{Sex}(\mathrm{SXHH})$ & 2 & Sex of the respondents ( 1 for male and 0 for female) \\
\hline Farming experience FREXP) & 1 & Farming experience in years \\
\hline Education (EDULVL) & 1 & Schooling years of the respondents \\
\hline Land holding (LNDSZ) & 1 & Land holding in hectare \\
\hline Income (INCO) & 1 & Total annual income of the respondents in Ethiopian Birr \\
\hline Access to credit (CRDTAC) & 2 & Access to credit ( 1 yes and 0 no) \\
\hline Livestock (LVST) & 1 & Livestock holding in Tropical Livestock Unit(TLU) \\
\hline Labor $(L A B R)$ & 1 & Labor in Man Equivalent \\
\hline Contact with extension agent (DACON) & 1 & $\begin{array}{l}\text { Number of contact made with development agents during the last } 12 \text { months prior to the survey } \\
\text { period }\end{array}$ \\
\hline Membership (SOCORG) & 2 & $\begin{array}{l}\text { Household head membership in any social organizations operating in the locality ( } 1 \text { for yes and } 0 \text { for } \\
\text { no) }\end{array}$ \\
\hline Participation in training (TRANN) & 2 & Respondents participation in agricultural extension training ( 1 for yes and 0 for no) \\
\hline Market distance (MKTDS) & 1 & Distance to the main market center in $\mathrm{km}$ \\
\hline Exposure to mass media (MASSM) & 2 & Exposure to mass media ( 1 for yes and 0 for no) \\
\hline Attitude (ATTD) & 2 & Respondents attitude towards wheat production technology ( 1 for positive and 0 for negative) \\
\hline
\end{tabular}

1 represents continuous variable and 2 represents dummy variable 
Table 2 Tobit model result

\begin{tabular}{|c|c|c|c|c|c|c|c|}
\hline Variable & Coef. & Std. Err & $t$-value & $p$-value & $\mathrm{a}$ & b & c \\
\hline $\mathrm{SXHH}$ & 0.033 & 0.054 & 0.61 & 0.546 & 0.00124 & 0.00326 & 0.00358 \\
\hline AGEHH & -0.005 & 0.002 & $-2.53^{* *}$ & 0.013 & -0.00031 & -0.00459 & -0.00474 \\
\hline EDULVL & 0.011 & 0.006 & $1.88^{*}$ & 0.063 & 0.00070 & 0.01029 & 0.01063 \\
\hline FMSZ & 0.014 & 0.010 & 1.31 & 0.191 & 0.00156 & 0.02373 & 0.02297 \\
\hline MASSM & 0.050 & 0.038 & 1.31 & 0.192 & 0.00753 & 0.02193 & 0.01947 \\
\hline LABR & 0.009 & 0.016 & 0.61 & 0.546 & 0.002591 & 0.03684 & 0.00313 \\
\hline SOCORG & 0.024 & 0.010 & $2.32^{* *}$ & 0.022 & 0.00156 & 0.02373 & 0.02297 \\
\hline ATTD & 0.018 & 0.004 & $4.35^{* * *}$ & 0.000 & 0.00193 & 0.01757 & 0.01815 \\
\hline FREXP & 0.004 & 0.003 & 1.23 & 0.223 & 0.00189 & 0.00984 & 0.00893 \\
\hline INCO & 0.000 & 0.000 & $2.76^{* * *}$ & 0.007 & $5.38 \mathrm{e}-07$ & 7.93 e-06 & $8.19 \mathrm{e}-06$ \\
\hline LNDSZ & 0.067 & 0.036 & $1.87^{*}$ & 0.063 & 0.00438 & 0.064473 & 0.06660 \\
\hline TRANN & 0.029 & 0.042 & 0.69 & 0.488 & 0.00871 & 0.002573 & 0.003124 \\
\hline CRDTAC & 0.072 & 0.040 & $1.79^{*}$ & 0.076 & 0.00472 & 0.06949 & 0.07179 \\
\hline MKTDS & -0.031 & 0.009 & $-3.44^{* * *}$ & 0.001 & -0.00201 & -0.02956 & -0.03054 \\
\hline DACON & 0.073 & 0.056 & 1.31 & 0.194 & 0.009813 & 0.000852 & 0.000971 \\
\hline Sigma & 0.2153128 & & 0.0135883 & & & & \\
\hline \multicolumn{8}{|c|}{ Log likelihood = - 1.2123948} \\
\hline \multicolumn{8}{|c|}{ ANOVA-based fit measure $\left(R^{2}\right)=0.953$} \\
\hline
\end{tabular}

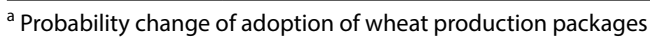

${ }^{b}$ Adoption intensity change

${ }^{c}$ Adoption total change

mobility and eagerness to gather new information about new technology is limited. Several studies conducted on the adoption of agricultural technology are consistent with the finding of this study. A study conducted by Bilaliib [28] in Ghana on factors influencing the agricultural technology adoption found that age negatively determines the adoption of agricultural technology. According to the finding of this study, as a farmer advances in age they turn to adopt technologies less as compared to the young farmers justifying as farmers grow older, there is an increase in risk aversion and a decreased interest in long-term investment in the farm. Furthermore, a study conducted by Refs. [7, 8] is consistent with this finding.

\section{Educational level of the household head}

As expected, education positively and significantly influence the probability of adoption and intensity of use of improved wheat technology at $10 \%$ significant level. The results show that, a one year increase in educational attainment of the respondents increases the probability of adoption of improved wheat production technology by $0.07 \%$. Similarly, it increases the intensity of use of improved wheat production technology by $1.029 \%$. This shows that in the study area, adopters are relatively more educated which helps them to adopt the new technologies more than their counterparts. The implication is farmers with higher educational background would have a better opportunity to access information and can easily understand the benefit of improved wheat technology packages. A study conducted by Refs. [10-12] and Ref. [29] reported positive and significant influence of household heads' educational level on adoption and intensity of adoption of agricultural technology package.

\section{Membership in social organization}

Membership in social organization positively and significantly determines the probability of adoption and intensity of adoption of improved wheat production technology at 5\% significance level. The model result confirms that being a member in social organizations increases probability of adoption and intensity of adoption of improved wheat production technology by $0.156 \%$ and $2.273 \%$, respectively, keeping the other factors constant. This implies that participation in social organization increases social networks and share of information on technology which increases adoption of these technologies. A study by Ref. [11] reached the same conclusion.

\section{Attitude towards wheat production technology package}

It was found that the attitude towards wheat production positively and significantly determines adoption and intensity of adoption of the improved what production technology at less than $1 \%$ probability level. In Table [2], the marginal effect of attitude towards wheat production 
technology package shows that positive attitude towards improved wheat production technology increases adoption and intensity of adoption of improved wheat production technology by $0.193 \%$ and $1.757 \%$, respectively, keeping the other factors constant. This implies that attitude of farmers is one of the major factors that determine their adoption decision towards any technologies. If farmers have positive attitude towards agricultural technologies their tendency of adopting it would be higher, otherwise they do not believe they would be productive. The result of this study goes along with the findings of Ref. [13] and Ref. [14].

\section{Access to credit}

Access to credit was also another institutional variable that was found to influence significantly the probability of adoption and intensity of adoption of improved wheat production technology at less than at $10 \%$. The marginal effect of tobit model shows that access to credit increase the probability of adoption and intensity of adoption of improved wheat technology by $0.472 \%$ and $6.949 \%$, respectively, keeping the other factors constant. This implies that access to credit is very crucial in adopting wheat production technology. There are a different wheat production technology that needs access to finance including weeding, land preparation, fertilizer purchase and application, and hiring labor. Access to finance is one of the engines for adoption and intensity of adoption of wheat production technology in the study area. The earlier study made by Refs. [10,15] and Ref. [11] are in agreement with this finding.

\section{Distance to the market}

The empirical results of the tobit model show that market distance negatively determines probability of adoption and intensity of adoption of wheat production technology at less than $1 \%$ significance level. As shown in Table [2], $1 \mathrm{~km}$ increase in distance away from the market center decreases the probability of adoption and intensity of use of improved wheat technology by $0.201 \%$ and $2.956 \%$, respectively. This shows that as market distance increases, the likelihood of farmers to adopt wheat technology package declines. The possible reason might be farmers nearer to the market center have access to market where they can easily access input for their agricultural production and sell their output for the market than those at far distance. Far market forces farmers to incur more cost to travel, spend more time and energy. As a result, farmer motivation to adopt new wheat technology package would be diminished. This result is similar with the finding of Ref. [15] and Ref. [11].

\section{Total land holding}

The model output revealed that farm size had positive and significant influence to the probability of adoption and intensity of use of improved wheat technology at less than $10 \%$ significance level. The marginal effect of tobit model analysis further showed that a unit hectare increase in the farm size of the household increases the probability of adoption and intensity of use of wheat production package by $0.438 \%$ and $6.4473 \%$, respectively. Generally in Ethiopia and particularly in Sidama, land is one of major productive assets where farmers carryout different agricultural production for their livelihood. Owning more land helps farmers to produce more for home consumption and sale when the production is surplus. Additional income obtained from the sale in turn helps farmers to invest in new agricultural technologies including wheat production. This finding supports the finding of earlier researches on technology like Refs. [11, $12]$ and Ref. [10].

\section{Annual income}

The tobit model output showed that annual income positively determines the probability of adoption and intensity of use of improved wheat technology at $1 \%$ significance level. The finding in this study supports the hypothesis that farmers with high annual income are more likely to adopt wheat technology packages than those farmers who have less annual income. The marginal effect of annual income in Table 2 above showed that increase in annual income by one birr increased the probability of adoption and intensity of adoption of wheat technology by $5.38 \mathrm{e}^{-07} \%$ and $7.93 \mathrm{e}^{-06 \%} \%$, respectively. This implies that income helps farmers to invest more in technology adoption which needs more finance and labor intensive, including wheat production technology. The result is consistent with Ref. [16].

\section{Conclusions and recommendations}

In this study, we analyzed the major determinants of adoption of improved wheat technology in Gorche district located in Sidama Regional State, Ethiopia. In doing so, we hypothesized different socio-economic, demographic, institutional and physiological factors that are assumed to affect farmers' decision towards technology adoption. Based on this, it was found that land holding in hectare, annual income of the household, level of education, membership in social institutions, access to credit, and positive attitude toward new wheat technology have positive and significant influence on the adoption and intensity of adoption of wheat production technology package. On the other hand, age and market distance have negative and significant 
influence on the adoption and intensity of adoption of the wheat production technology. It can be concluded that adoption and intensity of adoption of wheat production technology is a function of socio-economic, demographic, farmer's attitude and institutional factors. The policy implication of our study is that investment in education, strengthening social capital through available local social networks, provision of attitudefocused training and continuous technical support on wheat production technologies, improving income, expanding access to credit and market are important to facilitate the adoption of improved wheat production technologies. Therefore, addressing these constraints would improve the adoption and intensity of adoption of wheat production technologies. This in turn would help achieve food security of farmers generally in Ethiopia and specifically in Sidama.

\section{Abbreviations \\ SA: Seed applied per hectare; SNNP: South Nation Nationalities and People; SR: Seed recommended per hectare; FA: Fertilizer applied per hectare; FR: Fertilizer recommended per hectare; PFA: Plowing frequency applied; PFR: Plowing frequency recommended; WFA: Weeding frequency applied; WFR: Weeding frequency recommended; LCIWS: Land covered by improved wheat seed; LCTS: Land covered by total wheat seed.}

\section{Acknowledgements}

We would like to acknowledge sample farmers for their willingness to participate in this study.

\section{Authors' contributions}

AA wrote proposal, collected and fed data in Stata. ML participated in cleaning data and analysis. AA contributed data interpretation and article writing. All authors finally read the article before submission and agreed on it. All authors have read and approved the final manuscript.

\section{Funding}

Not applicable.

\section{Availability of data and materials}

The datasets used for this study will be available from the corresponding author on request.

\section{Declarations}

\section{Ethics approval and consent to participate}

Not applicable.

\section{Consent for publication}

The authors' confirm that the content of the manuscript has not been published, or submitted for publication elsewhere.

\section{Competing interests}

We declare that we do not have competing interests.

\section{Author details}

${ }^{1}$ Worabe Agricultural Research Center, South Agricultural Research Institute, Hawassa, Ethiopia. ${ }^{2}$ Department of Rural Development and Agricultural Extension, College of Agriculture, Hawassa University, Hawassa, Ethiopia.

Received: 20 September 2020 Accepted: 14 October 2021

Published online: 17 January 2022

\section{References}

1. Brasesco F, Asgedom D, Sommacal V, Casari G. Strategic analysis and intervention plan for wheat and wheat products in the Agro-Commodities Procurement Zone of the pilot Integrated Agro-Industrial Park in Central-Eastern Oromia. Addis Ababa: FAO; 2019.

2. CSA. Agricultural sample survey report on area and production of major crops. Statistical Bulletin Volume VI. 2014.

3. Nigussie A, Kedir A, Adisu A, Belay G, Gebrie D, Desalegn K. Bread wheat production in small scale irrigation users agro-pastoral households in Ethiopia: case of Afar and Oromia regional state. J Dev Agric Econ. 2014;7(4):123-30.

4. Anteneh A, Asrat D. Wheat production and marketing in Ethiopia: review study. Cogent Food Agric. 2020. https://doi.org/10.1080/23311932.2020. 1778893.

5. Gorched district bureau of agriculture. Annual report submitted to Sidama region, Hawassa, Ethiopia. 2019

6. Taro Y. Statistics: an introductory analysis. 2nd ed. New York: Harper and Row; 1967.

7. Gebremariam LT, Hagos H. Determinants of intensity of bread wheat packages adoption in Tigary, Northern Ethiopia. Turkish J Agric Food Sci Technol. 2018. https://doi.org/10.24925/turjaf.v6i9.1101-1107.1757.

8. Jaleta M, Kassie M, Marenya P. Impact of improved maize variety adoption on household food security in Ethiopia: an endogenous switching regression approach Paper presented on International conference of agricultural economists, Milan, Italy. 2015.

9. Mariapia M. Agricultural technology adoption and poverty reduction: a propensity-score matching analysis for rural Bangladesh. Food Policy. 2007. https://doi.org/10.1016/j.foodpol.2006.07.003.

10. Kebede WM, Tadesse D. Determinants affecting adoption of malt-barley technology: evidence from North Gondar Ethiopia. J Food Sec. 2015. https://doi.org/10.12691/jfs-3-3-2.

11. Kebedom A, Ayalew T. Analyzing adoption and intensity of use of coffee technology package in Yergacheffe District, Gedeo Zone, SNNP Regional State, Ethiopia. Int J Sci Res. 2014;3(10):1945-51.

12. A Aliye. Determinants of Adoption of Improved Durum Wheat (Triticum Durum) varieties in the Highlands of Bale: The Case of Agarfa District, Ethiopia. M.Sc. Thesis. Haramaya University. 2010.

13. I Jemal. Adoption of diary innovations: its income and gender implication in Adami Tulu district, Ethiopia. An M.Sc Thesis Submitted to School of Graduate Studies, Haramaya University. 2006.

14. M Sine. Assessment of Factors Influencing Adoption of Integrated Striga Management Technologies of, Sorghum in Habro and Fedis Woreda, or Mai Region. An M.Sc. Thesis Submitted to School of Graduate Studies of Haramaya University. 2007.

15. Endashawu S. Factors Affecting Adoption of Coffee Technology Packages in Wonsho woreda Sidama Zone; SNNP Regional state, Ethiopia. 2018.

16. Ketema MK. Determinants of Adoption of potato production technology package by smallholder farmers: from Eastern Ethiopia. 2016.

17 McDonald JF, Moffitt RA. The Uses of Tobit Analysis. Rev Econ Stat. 1980;62(2):318-21.

18 Dessie AB, Abate TM, Mekie TM. Factors affecting market outlet choice of wheat producers in North Gondar Zone, Ethiopia. Agric Food Sec. 2018. https://doi.org/10.1186/s40066-018-0241-x.

19. CSA. Agricultural sample survey; report on area and production of major crops, Vol I, CSA, Addis Ababa. 2017/2018.

20. Wakeyo MB, Lanos B. Analysis of price incentives for wheat in Ethiopia, Technical notes series, MAFAP. Rome: FAO; 2014.

21. Dibaba R, Goshu D. Determinants of high yielding wheat varieties adoption by small-holder farmers in Ethiopia. J Nat Sci Res. 2019. https://doi. org/10.7176/JNSR.

22. Hagos BG. Impact of agricultural technology adoption of small holder farmers on wheat yield: empirical evidence from Southern Tigrai State of Ethiopia. J Agric Ext Rural Dev. 2016;8(10):211-23.

23. Wake $R$. The determinants of high yielding wheat varieties adoption by small-holder farmers in Ethiopia. Dev Ctry Study. 2019. https://doi.org/10. 7176/DCS/9-1-01.

24 Wake R, Habteyesus D. Impact of high yielding wheat varieties adoption on farm income of smallholder farmers in Ethiopia. Int J Agric Ext. 2019. https://doi.org/10.33687/ijae.007.01.2490.

25. Solomon T, Tessema A, Bekele A. Adoption of improved wheat varieties in Robe and DigeluTijo Districts of Arsi Zone in Oromia Region, Ethiopia: 
a double-hurdle approach. Afr J Agric Res. 2014. https://doi.org/10.5897/ AJAR2014.9047.

26. Chandio AA, Jiang Y. Factors influencing the adoption of improved wheat varieties by rural households in Sindh, Pakistan. AIMS Agric Food. 2018. https://doi.org/10.3934/agrfood.2018.3.216.

27. Farooq A, Ishaq M, Yaqoob S, Sadozai KN. Varietal adoption effect on wheat crop production in irrigated areas of NWFP. Sarhad J Agric. 2007;23:481-5.

28. Udimal TB, Jincai Z, Mensah OS, Caesar AE. Factors influencing the agricultural technology adoption: the case of improved rice varieties (Nerica) in the Northern Region, Ghana. J Econ Sustain Dev. 2017;8(8):134.

29 Shiferaw B, Kassie M, Jaleta M, Yirga C. Adoption of improved wheat varieties and impacts on household food security in Ethiopia. Food Policy. 2014. https://doi.org/10.1016/j.foodpol.2013.09.012.

30. Maddala GS. Limited dependent and qualitative variables in econometrics. Cambridge: Cambridge University Press; 1997.

\section{Publisher's Note}

Springer Nature remains neutral with regard to jurisdictional claims in published maps and institutional affiliations.

- fast, convenient online submission

- thorough peer review by experienced researchers in your field

- rapid publication on acceptance

- support for research data, including large and complex data types

- gold Open Access which fosters wider collaboration and increased citations

- maximum visibility for your research: over $100 \mathrm{M}$ website views per year

At BMC, research is always in progress.

Learn more biomedcentral.com/submissions 